\title{
ANALISIS TINGKAT KEPERCAYAAN DAN KEPUASAN PELANGGAN TERHADAP NIAT UNTUK MENGGUNAKAN KEMBALI LAYANAN TRANSPORTASI ONLINE DI ERA PANDEMI COVID-19
}

\author{
Indah Lestari \\ Program Studi Manajemen, Universitas Muhammadiyah Palopo \\ Email: ${ }^{1)}$ indahIstri122@gmail.com
}

\begin{abstract}
Abstrak
Adapun tujuan utama dari penelitian ini yaitu untuk menganalisis persepsi tingkat kepercayaan pelanggan dan pengetahuan subjektif dalam mempengaruhi niat untuk menggunakan kembali layanan transportasi online. Adapun populasi didalam penelitian ini yaitu pengguna layanan ride-hailing yang ada di Kota Palopo. Sampel pada penelitian ini diambil dengan menggunakan metode probability sampling yaitu dengan tekhnik pendekatan random sampling. Ukuran sampel diambil sebanyak 50 sampel. Metode analisis data yang digunakan yaitu metode analisis regresi linier berganda dengan bantuan aplikasi SPSS versi 25. Hasil penelitian bahwa berdasarkan uji simultan variabel kepercayaan dan kepuasan pelanggan berpengaruh signifikan terhadap niat menggunakan kembali layanan transportasi online. Selanjutnya berdasarkan hasil uji parsial bahwa untuk variabel kepercayaan berdampak signifikan terhadap niat menggunakan kembali layanan transportasi online. Sedangkan untuk variabel kepuasan pelanggan tidak berpengaruh signifikan terhadap niat menggunakan kembali layanan transportasi online.
\end{abstract}

Kata Kunci: Kepercayaan, Kepuasan Pelanggan, Niat Menggunakan Ulang, Transportasi Online, dan COVID19.

\begin{abstract}
The main purpose of this study is to analyze the perception of the level of customer trust and subjective knowledge in influencing the intention to reuse online transportation services. The population in this study is the ride-hailing service users in the City of Palopo. The sample in this study was taken using the probability sampling method, namely the technique of random sampling approach. The sample size was accepted as many as 50 samples. The data analysis method used is multiple linear regression analysis methods with the help of SPSS application version 25. The results of the study based on simultaneous test variables of trust and customer satisfaction significantly influence the intention to reuse online transportation services. Furthermore, based on the partial test results that for the variable trust has a significant impact on the intention to reuse online transportation services. As for customer satisfaction, the variable does not significantly influence the intention to reuse online transportation services.
\end{abstract}

Keywords: Trust, Customer Satisfaction, Reuse Intention, Online Transportation, and COVID-19.

\section{PENDAHULUAN}

Era rovolusi industry 4.0 telah membawa dampak perubahan pada kehidupan manusia. Era ini salah satunya ditandai dengan semakin pesatnya perkembangan teknologi, yang mampu mengintegrasikan seluruh rangakaian aktifitas pekerjaan kedalam dunia virtual tanpa harus bertemu secara langsung. Perkembangan teknologi telah merambah ke bisnis transportasi digital yang ditandai dengan munculnya bisnis transportasi online yaitu Uber, Grab, dan Go-Jek. Layanan ini merupakan layanan yang memiliki sejumlah keunggulan yaitu kemudahan penggunaan, waktu tunggu yang singkat, serta harga yang terjangkau (Nguyen-Phuoc, Nguyen, De Gruyter, Su, \& Nguyen, 2019).

Indonesia merupakan salah satu negara yang memiliki pangsa pasar bisnis tansportasi berbasis digital. Kondisi ini didukung dengan penetrasi pengguna internet di Indonesia, dimana dari total 171,17 juta jiwa 64,8\% merupakan pengguna internet (APJII, 2019). Tentunya ini merupakan peluang besar bagi provider yang bergerak dalam bisnsi transportasi berbasis digital.

Namun demikian, kondisi perekonomian global saat ini dihadapkan dengan permasalahan yang serius, penyebabnya tidak lain adalah corona virus (COVID-19). Penyebaran virus ini 
terbilang sangat cepat dan sudah sampai ke beberapa negara di belahan dunia.Virus ini telah menjadi pandemi global, dimana akan sangat berdampak terhadap kestabilan perekonomian salah satunya dunia usaha.

Kondisi perekonomian global saat ini dihadapkan dengan permasalahan yang serius, penyebabnya tidak lain adalah corona virus (COVID-19). Penyebaran virus ini terbilang sangat cepat dan sudah sampai ke beberapa negara di belahan dunia.Virus ini telah menjadi pandemi global, dimana akan sangat berdampak terhadap kestabilan perekonomian salah satunya dunia usaha. Imbasnya, bisnis transportasi merupakan salah satu bisnis yang telah merasakan dampak dari pandemi corona virus (COVID-19). Dampak ini terlihat jelas salah satunya pada moda transportasi berbasis teknologi digital. Dari sudut pandang bisnis jasa transportasi publik berbasis online, gejala ini membuat beberapa layanan jasa transportasi online di Indonesia mengalami penurunan order yang berdampak terhadap omset. Pandemi corona virus (COVID-19) saat ini telah merubah pola interaksi dan gaya hidup manusia. Adanya pemberlakuan physical distancing serta imbauan untuk melakukan isolasi mandiri atau yang dikenal dengan istilah "stay at home" menyebabkan ruang gerak terbatas dan minim mobilitas. Kondisi ini akan berdampak terhadap kepuasan dan kepercayaan pengguna jasa layaan transportasi online. Keamanan akan ancaman penularan corona virus (COVID-19) akan berdampak terhadap kepuasan dan kepercayaan pengguna untuk menggunakan kembali layanan transportasi online.

Dari sudut pandang mode transportasi beberapa hasil penelitian telah melakukan investigasi dan eksplorasi terhadap kepuasan pelanggan dan continuance intention berdasarkan perspektif yang berbeda. Beberapa dari penelitian tersebut menghasilkan kerangka kerja konseptual yang baru. Diantaranya hasil penelitian yang dilakukan oleh (NguyenPhuoc, Su, Tran, Le, \& Johnson, 2020) (NguyenPhuoc et al., 2019) (Cheng, Fu, \& de Vreede, 2018). Dari beberapa hasil penelitian sebelumnya masih sangat terbatas yang melakukan investigasi dan eksplorasi terhadap kepuasan pelanggan dan continuance intention pada layanan trasnportasi online. Penelitian ini juga memiliki perbedaan dari beberapa penelitian yang telah dilakukan sebelumnya. Penelitian akan memberikan informasi penting mengenai eksistensi moda transportasi ridehailing dalam mempertahankan kepuasan dan kepercayaan pelanggan ditengah pandemi coronavirus yang terjadi di Indonesia. Adapun tujuan utama dari penelitian ini yaitu untuk menganalisis tingkat kepuasan pelanggan dan kepercayaan terhadap niat untuk menggunakan kembali layanan transportasi online.

\section{TINJAUAN PUSTAKA}

\section{Kepuasan Pelanggan}

Kepuasan merupakan salahsatu konsep utama dalam bidang pemasaran. Menurut (Oliver R. L., 1980) kepuasan merupakan keadaan psikologis ketika harapan bertemu dengan perasaan yang dialami oleh konsumen atas pengalaman mereka dalam menggunakan atau mengkonsumsi suatu produk atau layanan jasa. Kepuasan pelanggan merupakan salah satu faktor yang mampu berdampak terhadap sikap pelanggan, dan ini akan berlanjut mempengaruhi perilaku pembelian secara berulang (Oliver R. L., 1980). Menurut (S. C. Chen, 2012) semakin tinggi kepuasan seseorang maka semakin positif sikap yang dimiliki konsumen.

\section{Kepercayaan (Trust)}

Kepercayaan pelanggan dapat dikonseptualisasikan sebagai keadaan psikologis yang memotivasi seseorang untuk menerima akibat yang tidak dapat diduga sebelumnya, dan secara khusus didasarkan pada harapan yang menguntungkan mengenai niat dan perilaku dari pihak lain (Singh \& Sirdeshmukh, 2000; Sanchez-Franco, 2009) Pada penelitian ini kepercayaan (trust) berfokus terhadap kepercayaan responden dalam menggunakan layanan ride-hailing di era pandemik COVID-19.

\section{Niat Menggunakan Kembali (Continuance Intetntion)}

Niat untuk menggunakan kembali suatu produk atau layanan jasa merupakan indikasi bahwa 
konsumen merasa puas dan yakin terhadap produk atau layanan tersebut. Niat beli ulang (repurchase intention) merupakan bagian dari apa yang direncanakan oleh konsumen yang memberikan dorongan terhadap kesediaannya untuk melakukan pembelian ulang atas produ yang telah dibeli sebelumnya (Schiffman \& Leslie L. Kanuk, 2004). Adanya pembelian kembali atas prosuk atau layanan jasa pada umumnya menjadi pertanda bahwa produk atau layanan tersebut dapat memenuhi ekspektasi yang diharpakan oleh konsumen untuk kesediaanya menggunakan kembali dalam jumlah yang lebih besar.

\section{METODE PENELITIAN}

\section{Jenis Penelitian}

Jenis penelitian ini adalah explanatory research yang mencoba menjelaskan hubungan kausal (sebab akibat). Metode pengumpulan data dilakukan dengan survei menggunakan instrumen kuesioner dengan tipe pertanyaan tertutup (closed-ended question).

\section{Populasi dan Sampel}

Adapun populasi didalam penelitian ini yaitu pengguna layanan ride-hailing yang ada di Kota Palopo. Sampel pada penelitian ini diambil dengan menggunakan metode probability sampling yaitu dengan tekhnik pendekatan random sampling. Ukuran sampel minimum dalam suatu penelitian adalah $10 \mathrm{x}$ jumlah variabel yang diteliti. Jumlah variabel yang diteliti dalam penelitian ini adalah 3 (variabel terikat + varaibel bebas), jadi ukuran sampel minimum untuk penelitian ini adalah $10 \times 3=30$. Sehingga jika peneliti mengambil sampel sebesar 50 responden berarti telah memenuhi ukuran minimum sampel untuk penelitian, Data yang digunakan didalam penelitian ini yaitu data primer yang bersumber dari penyebaran kuesioner dengan menggunakan skala likert.

\section{Metode Analisis Data}

Adapun metode analisis data yang digunakan pada penelitian ini yaitu analisis regresi linier berganda formulasikan sebagai berikut.

$\mathrm{Y}=\mathrm{b}_{0}+\mathrm{b}_{1} \mathrm{X}_{1}+\mathrm{b}_{2} \mathrm{X}_{2}+e_{i}$

Di mana:

$$
\begin{array}{ll}
\mathrm{Y} & =\text { Niat Menggunakan Ulang } \\
\mathrm{b}_{0} & =\text { Konstanta } \\
\mathrm{b}_{1}-\mathrm{b}_{2} & =\text { Koefisien regresi } \\
\mathrm{X}_{1} & =\text { Kepuasan Pelanggan } \\
\mathrm{X}_{2} & =\text { Kepercayaan } \\
e_{i} & =\text { error }
\end{array}
$$

\section{Indikator Pengukuran Variabel Penelitian}

Indikator pengukuran untuk variabel kepercayaan, kepuasan pelanggan, dan niat

\begin{tabular}{|c|c|c|}
\hline Variabel & Item & Deskripsi Indikator Pengukuran Variabel \\
\hline \multirow{4}{*}{$\begin{array}{l}\text { Kepuasan } \\
\text { Pelanggan }\end{array}$} & KP1 & $\begin{array}{l}\text { Dalam kondisi pandemi COVID-19, saya merasa puas pada } \\
\text { layanan ride-hailing (jasa antar jemput) dalam memenuhi } \\
\text { kebutuhan saya }\end{array}$ \\
\hline & KP2 & $\begin{array}{l}\text { Dalam kondisi pandemi COVID-19, layanan ride-hailing (jasa } \\
\text { antar jemput) merupakan salah satu solusi yang membantu saya } \\
\text { untuk memenuhi kebutuhan saya }\end{array}$ \\
\hline & KP3 & $\begin{array}{l}\text { Dalam kondisi pandemi COVID-19, Saya pikir saya membuat } \\
\text { keputusan yang benăr untuk menggunakan layanan ride-hailing } \\
\text { (jasa antar jemput) dalam memenuhi kebutuhan yang berkaitan } \\
\text { dengan kebutuhan saya }\end{array}$ \\
\hline & KP4 & $\begin{array}{l}\text { Pengalaman saya dalam menggunakan layanan ride-hailing (jasa } \\
\text { antar jemput) Dalam kondisi pandemi COVID-19, dapat } \\
\text { memuaskan saya }\end{array}$ \\
\hline Kepercayaan & K1 & $\begin{array}{l}\text { Dalam kondisi pandemi COVID-19 layanan ride-hailing (jasa } \\
\text { antar jemput) memiliki komitmen untuk mengutamakan } \\
\text { perlindungan terhadap pengguna dan lingkungan }\end{array}$ \\
\hline
\end{tabular}
untuk menggunakan kembali disajikan pada tabel 1 berikut:

\section{Tabel 1}

\section{Indikator Pengukuran untuk Variabel Kepuasan Pelanggan, Kepercayaan} dan Niat Menggunakan Ulang.

(Rita, Oliveira, \& Farisa, 2019); (Moriuchi \& Takahashi, 2016); (Bula)

(Y. S. Chen, 2010); (Marakanon \& Panjakajornsak, 2017); (Chang \& Chen, 2008); (Gefen \& Straub, 


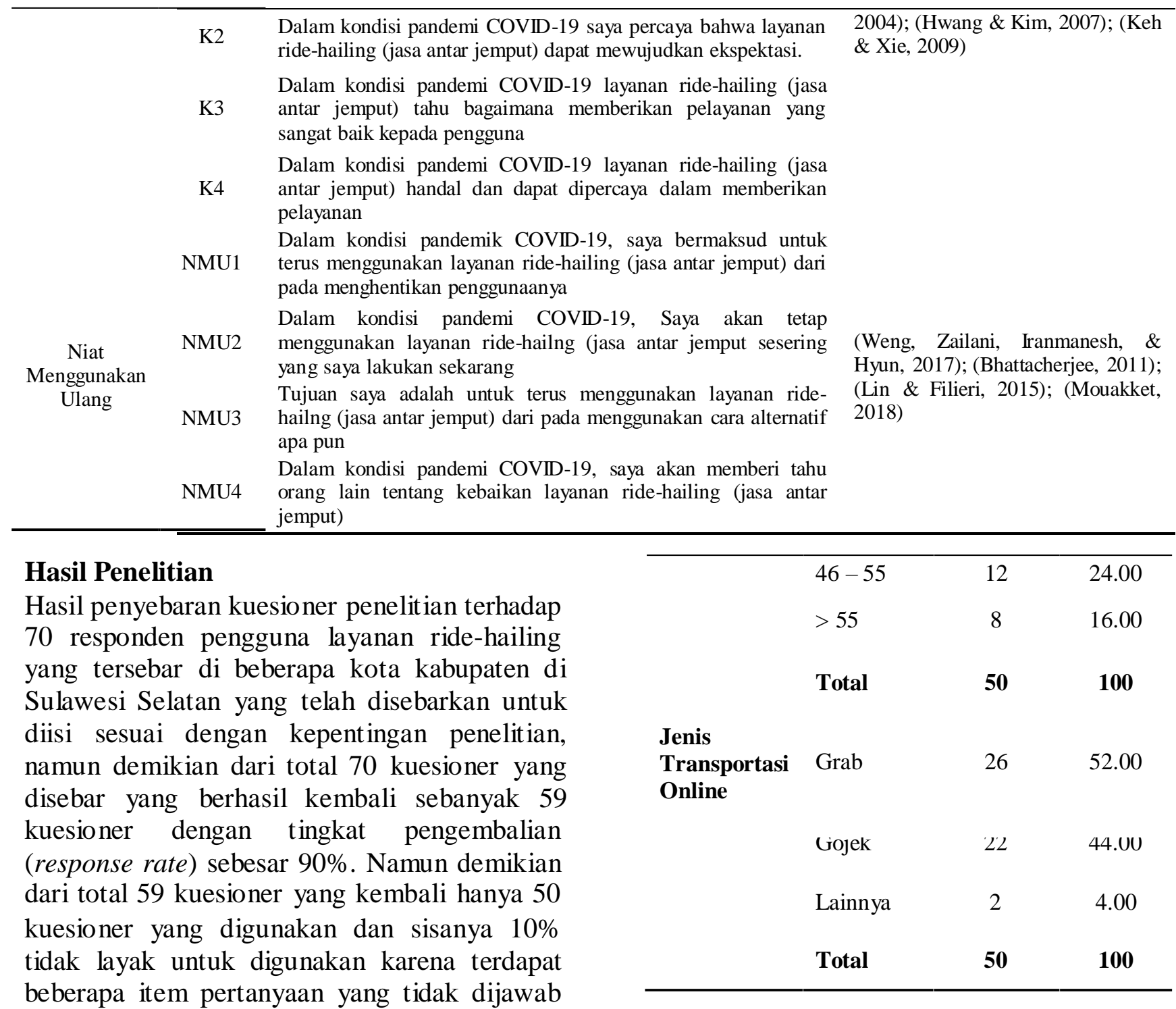
oleh responden pada saat pengisian kuesioner. Untuk karakteristik sampel penelitian bisa diamati dari gender, age, work status, kota kabupaten, dan jenis ride-hailing yang digunakan, secara rinci disajikan pada tabel 5.

Table 5. Karakteristik Responden

\begin{tabular}{|c|c|c|c|}
\hline \multirow{3}{*}{$\begin{array}{l}\text { Jenis } \\
\text { Kelamin }\end{array}$} & & ekuensi & $\%$ \\
\hline & Laki-Laki & 24 & 48.00 \\
\hline & Perempuan & 26 & 52.00 \\
\hline \multirow{3}{*}{ Age (years) } & Total & 50 & 100 \\
\hline & $26-35$ & 17 & 34.00 \\
\hline & $36-45$ & 13 & 26.00 \\
\hline
\end{tabular}

\section{Hasil Uji Validitas dan Reliabilitas}

Tabel. 3 Berikut disajikan hasil uji validitas dan reliabilitas untuk varaibel Kepuasan Pelanggan, Kepercayaan, dan Niat Menggunakan Ulang. 
Tabel 3

Hasil Uji Validitas dan Reliabilitas

\begin{tabular}{|c|c|c|c|c|c|c|c|}
\hline No & Variabel & Item & sig. hitung & alpha & $\begin{array}{c}\text { Cronbach } \\
\text { Alpha }\end{array}$ & \multicolumn{2}{|c|}{ Ket } \\
\hline \multirow{4}{*}{1} & \multirow{4}{*}{ Kepuasan Pelanggan } & KP1 & 0.000 & 0.05 & \multirow{4}{*}{0.802} & Valid & \multirow{4}{*}{ Reliabe } \\
\hline & & KP2 & 0.000 & 0.05 & & Valid & \\
\hline & & KP3 & 0.000 & 0.05 & & Valid & \\
\hline & & KP4 & 0.000 & 0.05 & & Valid & \\
\hline \multirow{4}{*}{2} & \multirow{4}{*}{ Kepercayaan } & K1 & 0.000 & 0.05 & \multirow{4}{*}{0.805} & Valid & \multirow{4}{*}{ Reliabe } \\
\hline & & $\mathrm{K} 2$ & 0.000 & 0.05 & & Valid & \\
\hline & & K3 & 0.000 & 0.05 & & Valid & \\
\hline & & K4 & 0.000 & 0.05 & & Valid & \\
\hline \multirow{4}{*}{3} & \multirow{4}{*}{$\begin{array}{c}\text { Niat Menggunakan } \\
\text { Ulang }\end{array}$} & NMU1 & 0.000 & 0.05 & \multirow{4}{*}{0.793} & Valid & \multirow{4}{*}{ Reliabe } \\
\hline & & NMU2 & 0.000 & 0.05 & & Valid & \\
\hline & & NMU3 & 0.000 & 0.05 & & Valid & \\
\hline & & NMU4 & 0.000 & 0.05 & & Valid & \\
\hline
\end{tabular}

Sumber: Data Primer, diolah 2020

Berdasarkan hasil uji validitas dan reliabilitas pada tabel 3, diperoleh informasi bahwa untuk setiap item pernyataan yang diajukan didalam penelitian ini dimana masing masing variabel terkategori valid. Untuk kepuasan pelanggan yang diukur menggunakan empat pernyataan, dimana keseluruhan memiliki nilai sig. hitung $<0.05$. Selanjutnya untuk setiap variabel terkategori reliabel karena memiliki nilai cronbacg alpha $>0.60$.

\section{Koefisien Determinasi}

Analisis ini digunakan untuk mengetahui besarnya proporsi dari variabel kepuasan pelanggan dan kepercayaan terhadap nilat menggunakan ulang layanan transportasi online.

\section{Tabel 4}

\section{Koefisien Determinasi/ $R$ Square}

\begin{tabular}{|c|c|c|c|c|}
\hline \multirow[b]{2}{*}{ Mod } & & \multicolumn{2}{|c|}{ Model Summary } & \multirow{3}{*}{$\begin{array}{l}\text { Std. Error of } \\
\text { the Estimate }\end{array}$} \\
\hline & & $\mathrm{R}$ & Adjusted R & \\
\hline el & $\mathrm{R}$ & Square & Square & \\
\hline 1 & $.368^{\mathrm{a}}$ & .135 & .098 & 2.61229 \\
\hline
\end{tabular}

Sumber: Data Primer, diolah 2020

Dari hasil analisis diperoleh nilai $\mathrm{R}$ Square $\left(\mathrm{R}^{2}\right)$ sebesar 0.135 artinya bahwa variasi perubahan variabel niat menggunakan ulang layanan transportasi online sebesar $13.5 \%$ secara bersama-sama disebabkan oleh variabel bebas yang terdiri dari variabel kepuasan pelanggan dan kepercayaan. Sedangkan sisanya sebesar $86.5 \%$ disebabkan oleh variabel lain yang tidak teridentifikasi kedalam model.

\section{Uji Simultan (Uji F)}

Pengujian ini dimaksud untuk mengetahui bagaimana variabel bebas yang terdiri dari variabel kepuasan pelanggan dan kepercayaan secara bersama-sama berpengaruh terhadap niat menggunakan ulang layanan transportasi online.

\section{Tabel 5}

\section{Hasil Uji Secara Simultan (Uji F)}

\begin{tabular}{|c|c|c|c|c|c|c|}
\hline \multicolumn{7}{|c|}{$\mathbf{A N O V A}^{\mathrm{a}}$} \\
\hline \multicolumn{2}{|c|}{ Model } & $\begin{array}{l}\text { Sum of } \\
\text { Squares }\end{array}$ & Df & $\begin{array}{l}\text { Mean } \\
\text { Square }\end{array}$ & $\mathrm{F}$ & Sig. \\
\hline \multirow[t]{3}{*}{1} & Regression & 50.149 & 2 & 25.074 & 3.674 & $.033^{\mathrm{b}}$ \\
\hline & Residual & 320.731 & 47 & 6.824 & & \\
\hline & Total & 370.880 & 49 & & & \\
\hline
\end{tabular}

a. Dependent Variable: NiatMenggunakanUlang

b. Predictors: (Constant), KepuasanPelanggan, Kepercayaan

Sumber: Data Primer, diolah 2020

Dari hasil perhitungan pada tabel 5 diketahui bahwa: $F_{\text {hitung }}=3.674>F_{\text {tabel }}=3,195$ atau tingkat signifikan sebesar 0.033 lebih kecil jika dibandingkan dengan tingkat $\alpha=5 \%$ berarti bahwa dari kepuasan pelanggan dan kepercayaan secara bersama-sama berpengaruh 
signifikan terhadap niat menggunakan ulang layanan transportasi online.

\section{Pengujian Secara Parsial}

Pengujian secara parsial (uji-t) dimaksud untuk mengetahui tingkat signifikan antara variabel terikat secara statistik adalah sebagai berikut:

\section{Tabel 6} Hasil Uji Secara Parsial (Uji t)

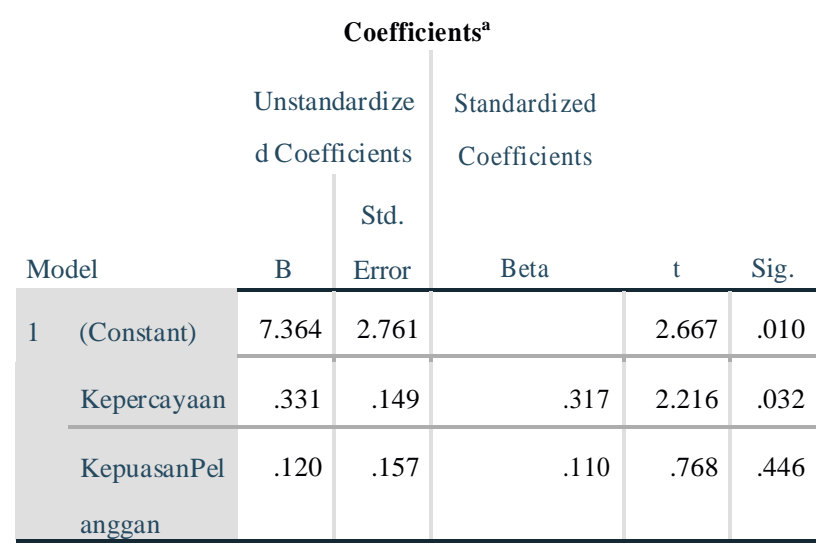

a. Dependent Variable: NiatMenggunakanUlang

Sumber: Data Primer, diolah 2020

\section{Kepercayaan}

Dari hasil perhitungan di ketahui bahwa variabel kepercayaan menghasilkan nilai $t_{\text {hitung }}$ $=2.216>\mathrm{t}_{\text {tabel }}=2.012$ atau tingkat signifikan sebesar 0.032 lebih kecil jika dibandingkan dengan tingkat $\alpha=5 \%$. Berdasarkan hasil perhitungan tersebut menunjukkan bahwa ada pengaruh positif dan signifikan antara kepercayaan terhadap niat menggunakan ulang layanan transportasi online.

\section{Kepuasan Pelanggan}

Dari hasil perhitungan di ketahui bahwa variabel kepuasan pelanggan menghasilkan nilai $t_{\text {hitung }}=0.768<\mathrm{t}_{\text {tabel }}=2.012$ atau tingkat signifikan sebesar 0.446 lebih besar jika dibandingkan dengan tingkat $\alpha=5 \%$. Berdasarkan hasil perhitungan tersebut menunjukkan bahwa kepuasan pelanggan berpengaruh positif tidak signifikan terhadap niat menggunakan ulang layanan transportasi online.

\section{Pembahasan Hasil Penelitian}

Pengaruh variabel bebas secara simultan (Uji F) yang meliputi kepercayaan dan kepuasan pelanggan terhadap niat menggunakan ulang layanan transportasi online

Berdasarkan hasil uji secara simultan (Uji F) dalam analisis regresi linear berganda pada penelitian ini diketahui bahwa tingkat signifikan sebesar 0.033 lebih kecil jika dibandingkan dengan tingkat $\alpha=5 \%$ berarti bahwa semua variabel bebas yang meliputi kepercayaan dan kepuasan pelanggan, secara bersama-sama mempunyai pengaruh yang signifikan terhadap variabel niat menggunakan ulang layanan transportasi online. Selanjutnya untuk besaran pengaruh semua faktor-faktor yang meliputi kepercayaan dan kepuasan pelanggan terhadap variabel niat menggunakan ulang layanan transportasi online sebesar 0.135 atau $13.5 \%$. Kemudian sisanya dipengaruhi oleh faktor lain secara variabel bebas pada penelitian ini sebesar 4,3\%.

\section{Pengaruh variabel kepercayaan terhadap niat menggunakan ulang layanan transportasi online}

Berdasarkan hasil penelitian dengan pengujian secara parsial (Uji-t) yang menunjukkan bahwa variabel kepercayaan berpengaruh positif signifikan terhadap niat menggunakan ulang layanan transportasi online dengan koefisien regresi sebesar 0.331 atau $33.1 \%$ artinya dengan meningkatnya variabel kepercayaan akan meningkat pula niat menggunakan ulang layanan transportasi online diikuti dengan perubahan peningkatan yang signifikan, ini dapat dilihat dari tingkat signifikan yaitu sebesar 0.032. Hasil temuan ini sejalan dengan apa yang dikemukakan oleh (Singh \& Sirdeshmukh, 2000; Sanchez-Franco, 2009) bahwa kepercayaan pelanggan dapat dikonseptualisasikan sebagai keadaan psikologis yang memotivasi seseorang untuk menerima akibat yang tidak dapat diduga sebelumnya, dan secara khusus didasarkan pada harapan yang menguntungkan mengenai niat dan perilaku dari pihak lain. Adanya himbauan isolasi mandiri atau "stay at home" dari pemerintah dengan tujuan untuk memutus rantai penyebaran corona virus (COVID-19). Kondisi ini telah membawa perubahan pada pola rutinitas yang berbeda dengan pembatasan ruang gerak serta minimnya mobilitas. Namun demikian, layanan jasa transportasi online 
masih tetap beroperasi dan mendapat kepercayaan dari publik untuk tetap memberikan pelayanan. Jasa transportasi online masih dipersepsikan dengan baik oleh publik, dimana layanan ini dipercaya bisa menjadi solusi untuk membantu serangkaian aktivitas publik seperti pelayanan terhadap jasa pengantaran bahan kebutuhan sehari hari seperti makanan, pengiriman paket dan beberapa layanan lain.

\section{Pengaruh variabel kepuasan pelanggan terhadap niat menggunakan ulang layanan transportasi online}

Berdasarkan hasil penelitian dengan pengujian secara parsial (Uji-t) yang menunjukkan bahwa variabel kepuasan pelangan berpengaruh positif tidak signifikan terhadap niat menggunakan ulang layanan transportasi online dengan koefisien regresi sebesar 0.120 atau $12 \%$ artinya dengan meningkatnya kepuasan pelangan tidak akan berdampak terhadap meningkatnya niat menggunakan ulang layanan transportasi online. Hal diikuti dengan perubahan peningkatan yang tidak signifikan, ini dapat dilihat dari tingkat signifikan yaitu sebesar 0.446 . Hasil temuan ini tidak sejalan dengan apa yang dikemukakan oleh (Oliver R. L., 1980; Ikbal \& Hamid, 2016) bahwa kepuasan pelanggan merupakan salah satu faktor yang mampu berdampak terhadap sikap pelanggan, dan ini akan berlanjut mempengaruhi perilaku pembelian secara berulang. Meskipun layanan transportasi online masih dipercayai oleh publik, namun masih belum mampu memberikan dampak terhadap kepuasan. Hal ini tentunya disebabkan karena tidak semua aktivitas atau keperluan publik bisa terpenuhi dengan layanan transportasi online.

\section{SIMPULAN}

Berdasarkan hasil analisis dan pembahasan yang telah diuraikan sebelumnya, maka ada beberapa poin penting yang dihasilkan pada penelitian ini. Pertama secara simultan variabel kepercayaan dan kepuasan pelanggan berpengaruh signifikan terhadap niat menggunakan ulang layanan transportasi onine di Kota Palopo. Selanjutnya, berdasarkan uji parsial diperoleh informasi hasil temuan penelitian bahwa dari dua variabel yang diusulkan pada model penelitian, terdapat satu variabel yang berdampak signifikan yaitu variabel kepercayaan. Selanjutnya untuk pengaruh variabel kepuasan pelanggan tidak berdampak signifikan terhadap niat menggunakan ulang layanan transportasi online. Dengan demikian hasil penelitian ini memberikan informasi penting bahwa dalam kondisi pandemi COVID-19, pengguna layanan transportasi online masih dipercaya oleh responden untuk digunakan kembali. Namun demikian hal itu belum mampu meningkatkan kepuasan mereka. Hal ini salah satunya disebabkan oleh adanya perubahan pola atau gaya hidup yang dialami oleh masyarakat di Kota Palopo di era pandemic COVID-19. Adanya penurunan mobilitas yang awalnya tinggi namun pada kondisi pandemi menurun, dimana pekerjaan tidak harus dilakukan dengan tatap muka secara langsung atau pemenuhan kebutuhan pokok yang tidak mengaruskan untuk ke supermarket atau ke pasar tradisional. Kondisi ini masih memberikan ruang bagi jasa transportasi online untuk bisa terus memberikan pelayanan kepada publik.

\section{DAFTAR PUSTAKA}

APJII. (2019). Penetrasi \& Profil Perilaku Pengguna Internet Indonesia Tahun 2018. Apjii, 51. Retrieved from www.apjii.or.id

Belanche, D., Casaló, L. V., \& Guinalíu, M. (2012). Website usability, consumer satisfaction and the intention to use a website: The moderating effect of perceived risk. Journal of Retailing and Consumer Services, 19(1), 124-132. https://doi.org/10.1016/j.jretconser.2011.1 1.001

Bhattacherjee, A. (2011). Understanding Information Systems Continuance: An Expectation-Confirmation Model. MIS Quarterly, 25(3), 351-370. https://doi.org/10.2307/3250921

Chang, H. H., \& Chen, S. W. (2008). The impact of online store environment cues on purchase intention: Trust and perceived 
risk as a mediator. Online Information Review, 32(6), 818-841. https://doi.org/10.1108/146845208109239 53

Chen, S. C. (2012). The customer satisfactionloyalty relation in an interactive e-service setting: The mediators. Journal of Retailing and Consumer Services, 19(2), 202-210.

https://doi.org/10.1016/j.jretconser.2012.0 1.001

Chen, Y. S. (2010). The drivers of green brand equity: Green brand image, green satisfaction, and green trust. Journal of Business Ethics, 93(2), 307-319. https://doi.org/10.1007/s10551-009-02239

Cheng, X., Fu, S., \& de Vreede, G. J. (2018). A mixed method investigation of sharing economy driven car-hailing services: Online and offline perspectives. International Journal of Information Management, 41(10), 57-64. https://doi.org/10.1016/j.ijinfomgt.2018.0 3.005

Gefen, D., \& Straub, D. W. (2004). Consumer trust in B2C e-Commerce and the importance of social presence: Experiments in e-Products and e-Services. Omega, 32(6), 407-424. https://doi.org/10.1016/j.omega.2004.01.0 06

Hwang, Y., \& Kim, D. J. (2007). Customer self-service systems: The effects of perceived Web quality with service contents on enjoyment, anxiety, and etrust. Decision Support Systems, 43(3), 746-760.

https://doi.org/10.1016/j.dss.2006.12.008

Ikbal, M., \& Hamid, R. S. (2016). Smartphone Use of Effectiveness in Supporting Young Entrepreneurs Business Activity in the Palopo Using Technology Acceptance Model (TAM). Information Management and Business Review, 8(1), 57-65.

Keh, H. T., \& Xie, Y. (2009). Corporate reputation and customer behavioral intentions: The roles of trust, identification and commitment. Industrial Marketing Management, 38(7), 732-742. https://doi.org/10.1016/j.indmarman.2008. 02.005

Lin, Z., \& Filieri, R. (2015). Airline passengers' continuance intention towards online check-in services: The role of personal innovativeness and subjective knowledge. Transportation Research Part E: Logistics and Transportation Review, 81 , $158-168$ https://doi.org/10.1016/j.tre.2015.07.001

Marakanon, L., \& Panjakajornsak, V. (2017). Perceived quality, perceived risk and customer trust affecting customer loyalty of environmentally friendly electronics products. Kasetsart Journal of Social Sciences, $38(1), \quad 24-30$. https://doi.org/10.1016/j.kjss.2016.08.012

Moriuchi, E., \& Takahashi, I. (2016). Satisfaction trust and loyalty of repeat online consumer within the Japanese online supermarket trade. Australasian Marketing Journal, 24(2), 146-156. https://doi.org/10.1016/j.ausmj.2016.02.0 06

Mouakket, S. (2018). The role of personality traits in motivating users' continuance intention towards Facebook: Gender differences. Journal of High Technology Management Research, 29(1), 124-140. https://doi.org/10.1016/j.hitech.2016.10.0 03

Nguyen-Phuoc, D. Q., Nguyen, H. A., De Gruyter, C., Su, D. N., \& Nguyen, V. H. (2019). Exploring the prevalence and factors associated with self-reported traffic crashes among app-based motorcycle taxis in Vietnam. Transport Policy, 81(November 2018), 68-74. https://doi.org/10.1016/j.tranpol.2019.06.0 06

Nguyen-Phuoc, D. Q., Su, D. N., Tran, P. T. K., Le, D. T. T., \& Johnson, L. W. (2020). Factors influencing customer's loyalty towards ride-hailing taxi services - A case study of Vietnam. Transportation Research Part A: Policy and Practice, 
134(March 2019), 96-112. https://doi.org/10.1016/j.tra.2020.02.008

Oliver R. L. (1980). A Cognitive Model of the Antecedents and Consequences of Satisfaction Decisions. Journal of Marketing Research, 17(4)(November), 460-469.

Rita, P., Oliveira, T., \& Farisa, A. (2019). The impact of e-service quality and customer satisfaction on customer behavior in online shopping. Heliyon, 5(10), e02690. https://doi.org/10.1016/j.heliyon.2019.e02 690

Sanchez-Franco, M. J. (2009). The Moderating Effects of Involvement on the Relationships Between Satisfaction, Trust and Commitment in e-Banking. Journal of Interactive Marketing, 23(3), 247-258. https://doi.org/10.1016/j.intmar.2009.04.0 07

Schiffman, L. G., \& Leslie L. Kanuk. (2004). Consumer Behavior. Eight Edition. New Jersey: Pearson Education, Inc.

Singh, J., \& Sirdeshmukh, D. (2000). Agency and trust mechanisms in consumer satisfaction and loyalty judgments. Journal of the Academy of Marketing Science, 28(1), 150-167. https://doi.org/10.1177/009207030028101 4

Weng, G. S., Zailani, S., Iranmanesh, M., \& Hyun, S. S. (2017). Mobile taxi booking application service's continuance usage intention by users. Transportation Research Part D: Transport and Environment, 57, 207-216. https://doi.org/10.1016/j.trd.2017.07.023 